\title{
OPERATING MODES OF COMPLEX HYDROPOWER SYSTEMS
}

\author{
Sofija Nikolova Poceva, Anton Čauševski \\ Faculty of Electrical Engineering and Information Technologies, \\ "Ss. Cyril and Methodius" University in Skopje, \\ P.O. box 574, 1001 Skopje, North Macedonia \\ nsofija@feit.ukim.edu.mk
}

\begin{abstract}
A b s t r a c t: The paper presents the methodology of operation modes for hydropower plants (conventional and pump storage) in a complex hydroenergy system. Operation involves water management in generating and/or pumping mode of hydropower units taking into accounts technical characteristics of the power plants facilities (turbine/generator and pump/motor systems), reservoirs characteristics considering all hydraulically connected infrastructures, as well as the hydrological conditions (for run offs and turbine inflows). The purpose of the operating mode for the entire hydropower system is to maximize financial profits from electricity generation, taking into account market electricity prices, electricity needs, with respecting the technical requirements and of course avoiding or minimizing overflow. Operating regimes depend on the electricity market price, the tariff models and the duration of each tariff (base, peak), the technical characteristics of the units and the hydrological conditions. The model application is presented at the hydropower Complex on the Crn Drim river with existing construction and new facilities that can be upgraded in the future. The results are presented for long-term and short-term planning of the system operation under various technical and hydrological conditions. The model can be used to perform preliminary analyses in order to improve hydroenergy systems with additional installed capacity of the existing system. Selected outputs are presented with appropriate comparisons and conclusions.
\end{abstract}

Key words: generation; hydropower plant; pump; operation modes

\section{РАБОТНИ РЕЖИМИ НА КОМПЛЕКСНИ ХИДРОЕНЕРГЕТСКИ СИСТЕМИ}

А п с т р а к т: Во трудот се презентира методологијата на оперативна работа на хидроцентрали (конвенционални и пумпно-акумулациони) во сложен хидроенергетски систем. Оперативноста вклучува управување со водите во генераторски и/или пумпен режим на хидроелектраните, земајќи ги предвид техничките карактеристики на производните постројки (турбина/генератор и пумпа/мотор), како и карактеристиките на акумулациите со хидрауличната инфраструктура поврзана со системот, како и хидролошките услови. Целта на оперативниот режим за целиот хидроенергетски систем е да се добие максимален профит од производството на електрична енергија, земајќи ги предвид пазарните цени на електрична енергија, потребите од електрична енергија, почитувајќ́ ги техничките услови и, секако, да се избегне или минимизира прелевање. Работните режими на хидроцентралите зависат од пазарнта цена на електрична енергија, тарифните модели и времето на траење на секоја тарифа (базна, највисока), техничките карактеристики на единиците и хидролошките прилики. Апликацијата на моделот е претставена на хидроенергетскиот комплекс на реката Црн Дрим со постојната изграденост и со нови објекти кои можат во иднина да се доградат. Резултатите се презентирани за долгорочно и краткорочно планирање на работата на системот при разни услови и хидролошки прилики. Моделот може да се користи за правење прелиминарни анализи за подобрување на хидросистемите со дополнително инсталирана моќност на постојниот систем. Избраните излезни резултати се презентирани со соодветно споредување и со заклучоци.

Клучни зборови:. производство; хидроелектрична централа; пумпа; оперативни режими

\section{INTRODUCTION}

The paper presents a model for different operation modes of hydraulically connected hydropower system (HPS) that consists of reservoirs, pipe-connected lines and hydropower plants. The operating modes can be distinguished depending on time interval planning (year, season or month for long term 
(LT) and week, few days or a day for short term (ST)). The model takes into account the technical specifications and the parameters of the whole system such as:

- Volume of the water reservoirs with limitation of minimal and maximum elevation of the reservoirs.

- Turbine units characteristics (flows, power).

- Other technical constraints and specifications of the elements of the hydropower system.

- Connected infrastructure of lines and pipes.

The model is applied on an existing hydropower system built on the Crn Drim river, by taking into account the existing power system as well as the other reservoirs and power generation units in new HPPs, which are considered to be built in next period.

\section{MODEL OF OPERATING MODES}

The model gives the main outputs of hydropower system depending on power system operator requirements and demand, and it takes into account the input of water run offs with respect to the system technical conditions. The modeling approaches depend on LT or ST operation modes. In the LT operation modes, the whole considering time period $(T)$ can be a year or a few years divided in months' or weeks' time intervals $(t)$ (it depends on the availability of hydrological data) and it mainly considers the large reservoirs. In the ST operation modes, the whole observed time period $(T)$ can be a week or several days divided in hourly intervals $(t)$ by mainly taking into account the water management for small reservoirs in a daily regulation. The output results from the model are the turbine discharges, and the electricity production of HPPs as well as the reservoir level for each time interval $(t)$ of the observed time period $T$. In order to simulate the operation regimes of the whole system, it is necessary to know the characteristics of the reservoirs. The modeling of the characteristic of the all reservoirs is done according [4], by making use of two functions: the volume dependence of the attitude and vice versa, and the attitude dependence of the volume expressed by (1) and (2), respectively:

$$
\begin{gathered}
V o l(A t t)=2 \cdot \pi \cdot\left(A+B \cdot A t t+C \cdot A t t^{2}\right) \\
A t t(V o l)=g+h \cdot(V o l-d)^{\mathrm{e}}
\end{gathered}
$$

The simulations of the operating regimes are done by taking into account the characteristics of the reservoirs, the water inflows and the turbine characteristics of the HPPs. The inputs in the model are: average inflows and run offs for the time intervals, the characteristic of the electric power output $P=f$ ( $\left.Q_{\mathrm{tur}}, H_{\mathrm{gross}}\right)$ as a function of the turbine flow $\left(Q_{\mathrm{tur}}\right)$ and the gross head and the reservoirs characteristics defined by (1) and (2). In order to perform a financial analysis, it is necessary to have the electricity prices. Therefore, the following conditions and assumptions are taking into accounts in the model:

- The reservoirs level are within the allowed limits and possible spilling is avoided.

- The turbine flow priority is to obtain maximum revenue from the generated electricity according to the electricity market prices for each period of the day.

Based on aforementioned criteria, the following output results can be obtained:

- consumed water volume in each time period (year, month, week and day) for each reservoir;

- output power for each time period $P(t)$;

- generated electricity for each time period $W(t)$;

- financial profit from the sold electricity (FIN).

The methodology for the operation modes of the hydropower plants can be used for different needs depending on the input data and the requirements requested by the utility or operator of the power plant.

Some of the possible applications are hydropower systems from simple to complex technical hydraulically configuration and connectivity for different time period of consideration $(T)$ as: few years, a year, season, week, only a day. The period of consideration can be divided in different time intervals $\Delta t_{i}$, where

$$
T=\sum_{i=1}^{n} \Delta t_{i} .
$$

\section{HYDROPOWER SYSTEM OF CRN DRIM (EXISTING AND ADDITIONAL UNITS)}

The existing hydropower system (HPS) of the Crn Drim river (Figure 1), consists of two hydropower plants (HPP Globočica $2 \times 21 \mathrm{MW}$ and full turbine discharge of $50 \mathrm{~m}^{3} / \mathrm{s}$ ) and HPP Špilje $\left(3 \times 28 \mathrm{MW}\right.$ and full turbine discharge of $\left.108 \mathrm{~m}^{3} / \mathrm{s}\right)$, three reservoirs (RES 1 - Ohrid Lake, RES 2 Globočica, and RES 3 - Debar Lake) with main run offs from two rivers (Crn Drim and Radika).

HPP Globočica with two units is the first upper stream power plant in HPS. Crn Drim is a derivative 
power plant that uses the water from RES 1 of Ohrid Lake. Each of the two units is $25 \mathrm{~m}^{3} / \mathrm{s}$ or $50 \mathrm{~m}^{3} / \mathrm{s}$ in total, with a total installed capacity of $42 \mathrm{MW}$, have gross head of $108-110 \mathrm{~m}$. The turbine flow from the Globočica HPP and the Radika river are the main runoffs for RES 3 of Debar Lake which is the reservoir of HPP Špilje. Existing HPP Špilje has 3 units with $36 \mathrm{~m}^{3} / \mathrm{s}$ each or $108 \mathrm{~m}^{3} / \mathrm{s}$ in total, with a gross head of $80-100 \mathrm{~m}$, and a total installed capacity of $84 \mathrm{MW}$. Figure 1 schematically presents the existing HPS of Crn Drim with planned new hydropower plants and new RES 4 - Tašmaruništa for new additional reversible HPP.

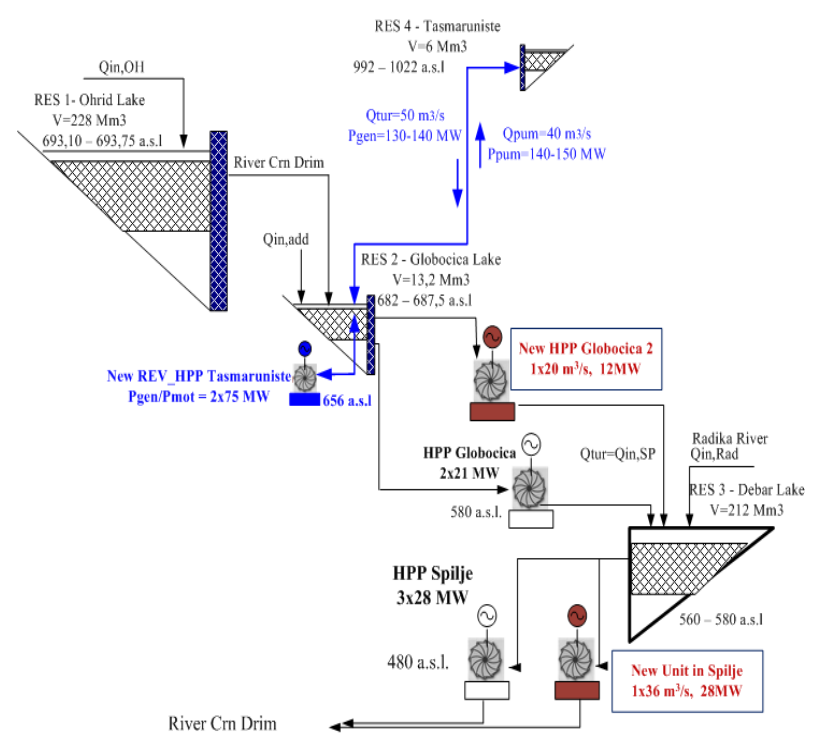

Fig. 1. Hydraulically connected HPS of Crn Drim (existing and new reservoirs and units)

The new generating units are in HPP Globočica 2 with a unit of $20 \mathrm{~m}^{3} / \mathrm{s}$ turbine flow and 12 MW installed power, located in the new turbine hall with a $70 \mathrm{~m}$ gross head. The additional unit in HPP Špilje has $36 \mathrm{~m}^{3} / \mathrm{s}$ turbine flow and $28 \mathrm{MW}$ installed power; the same as the existing ones which are located in the same turbine hall [1]. The new reversible (pump storage) HPP Tašmaruništa is added to the upper reservoir RES 4 of Tašmaruništa on the Crn Drim system. The others basic technical parameters (from [2] and [3]) as the reservoirs' volumes, the attitudes of the turbines, the minimum and maximum reservoir levels, the turbine flows and the installed power are given in Figure 1. Therefore, the whole hydropower system, which is considered in this paper, consists of four reservoirs with basic information shown in Table 1 and HPPs with some technical characteristics given on Table 2 .
The large reservoirs, RES 1 of Ohrid Lake and RES 3 of Debar Lake, are important for long-term analyses (seasonal, annual and multi-year). The small reservoirs, RES 2 of Globočica and RES 4 of Tašmaruništa, can be taken in short-term analyses as daily, several days or weekly analyses. The parameters obtained according to (1) for all reservoirs are given in Table $3 \mathrm{a}$.

The parameters according the formula (2) for all reservoirs are given in Table $3 \mathrm{~b}$.

Ta b l e 1

Characteristics of the reservoirs of the HPS of Crn Drim

\begin{tabular}{ccccc}
\hline \hline & \multicolumn{3}{c}{ Ex is ting } & New \\
& RES 1 & RES 2 & RES 3 & RES 4 \\
\hline Att.max (a.s.1.) & 693.75 & 687.5 & 580 & 1022 \\
Att.min (a.s.1.) & 693.10 & 682 & 560 & 992 \\
Vol. $\left(\mathrm{Mm}^{3}\right)$ & 228.00 & 13.20 & 212.00 & 6.00 \\
\hline \hline
\end{tabular}

Ta b le 2

HPPs characteristics in the HPS of Crn Drim

\begin{tabular}{ccccc}
\hline \hline & $\begin{array}{c}\text { No. of } \\
\text { units }\end{array}$ & $\begin{array}{c}Q_{\text {inst }} \\
\left(\mathrm{m}^{3} / \mathrm{s}\right)\end{array}$ & $\begin{array}{c}H_{\text {gross }} \\
(\mathrm{m})\end{array}$ & $\begin{array}{c}P_{\text {inst }} \\
(\mathrm{MW})\end{array}$ \\
\hline Exist. HPP Špilje & 3 & 108 & $75-95$ & 84 \\
Exist. HPP Globočica & 2 & 50 & $102-105$ & 42 \\
New HPP Špilje 4 unit & 1 & 36 & $75-95$ & 28 \\
New HPP Globočica 2 & 1 & 20 & 70 & 12 \\
New Rev HPP Tasm. & 2 & $\begin{array}{c}Q_{t}=50, \\
Q_{p}=40\end{array}$ & $305-335$ & 150 \\
\hline \hline
\end{tabular}

Table $3 a$

The parameters for all reservoirs according (1)

\begin{tabular}{cccc}
\hline \hline & $\mathrm{A}$ & $\mathrm{B}$ & $\mathrm{C}$ \\
\hline RES 1 & $1,64 \cdot 10^{6}$ & -4863 & 3.60 \\
RES 2 & 4135 & -13 & 0.01 \\
RES 3 & 5790 & -23 & 0.02 \\
RES 4 & 996 & -2 & 0.001 \\
\hline \hline
\end{tabular}

Table $3 b$

The parameters for all reservoirs according (2)

\begin{tabular}{ccccc}
\hline & $\mathrm{g}$ & $\mathrm{d}$ & $\mathrm{h}$ & $\mathrm{e}$ \\
\hline RES 1 & 675 & -3136 & 0.3 & 0.5 \\
RES 2 & 640 & -48 & 6.1 & 0.5 \\
RES 3 & 500 & -194 & 4 & 0.5 \\
RES 4 & 971 & $-1,2$ & 19 & 0.5 \\
\hline \hline
\end{tabular}




\subsection{Long term (LT) operation modes of HPS Crn Drim}

The simulations for the HPS of Crn Drim for LT operation modes are made on the monthly basis time interval ( $t=1$ month) during the whole period of the year ( $T=1$ year). The main idea of the simulation is to find the operational regimes with a maximum financial benefit under new market conditions with electricity prices present on the open market with different tariffs (Figure 2).

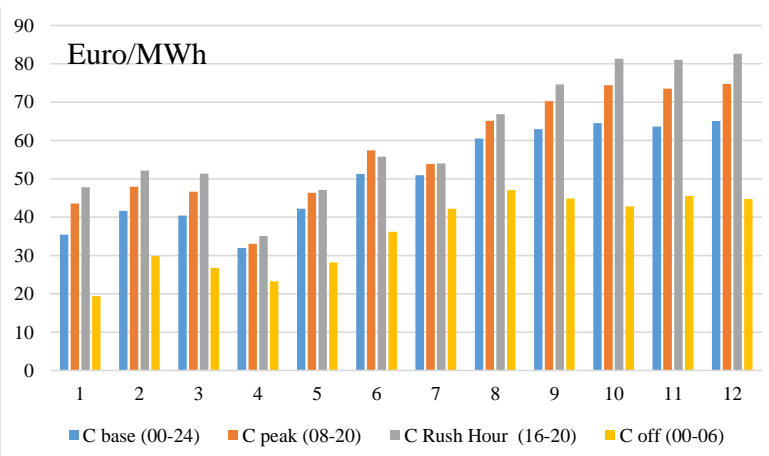

Fig. 2: Daily tariffs and electricity price $C(€ / \mathrm{MWh})$ from the HUPEX in 2018

The time periods for each day are divided into 2 groups (tariffs) for long-term operation modes (Base tariff $\left(C_{\text {base }}\right)$ and Peak tariff $\left.\left(C_{\text {peak }}\right)\right)$. The water inflow for HPP Globočica $\left(Q_{\mathrm{in}, \mathrm{GL}}\right)$ is predominantly from the Lake of Ohrid $\left(Q_{\mathrm{in}, \mathrm{OH}}\right)$, and the additional runoffs $\left(Q_{\text {in,add }}\right)$ :

$$
Q_{\mathrm{in,GL}}(t)=Q_{\mathrm{in}, \mathrm{OH}}(t)+Q_{\mathrm{in}, \mathrm{add}}(t)
$$

The water inflow for HPP Špilje $\left(Q_{\mathrm{in}, \mathrm{SP}}\right)$ mainly depends on the turbine flow of HPP Globočica $\left(Q_{\mathrm{tur}, \mathrm{GL}}\right)$ and the natural runoff from the Radika river $\left(Q_{\text {in,Rad }}\right)$ :

$$
Q_{\mathrm{in}, \mathrm{SP}}(t)=Q_{\mathrm{tur}, \mathrm{GL}}(t)+Q_{\text {in,Rad }}(t) .
$$

According to the natural flows obtained from the available hydrological data [2], three characteristic hydrological years have been selected in yearly operating modes: 2001 - as a dry year representative, 2006 - as an average year representative, and 2013 - as a wet year representative. Figures 3 and 4 show the monthly water inflows for the reservoirs in HPP Globočica and HPP Špilje, respectively, in each of the representative year.

The starting value of the reservoirs level at the $1^{\text {st }}$ of January is common for all simulations; for Ohrid Lake is 693.3 a.s.l. and for Debar Lake is 563 a.s.l. The simulation results are obtained for three years (dry 2001, average 2006 and wet 2013). The results of the representative of the wet year: the reservoir level of Ohrid Lake and the spent volume of water for HPP Globočica are presented in Figures $5 \mathrm{a}$ and $5 \mathrm{~b}$, respectively..

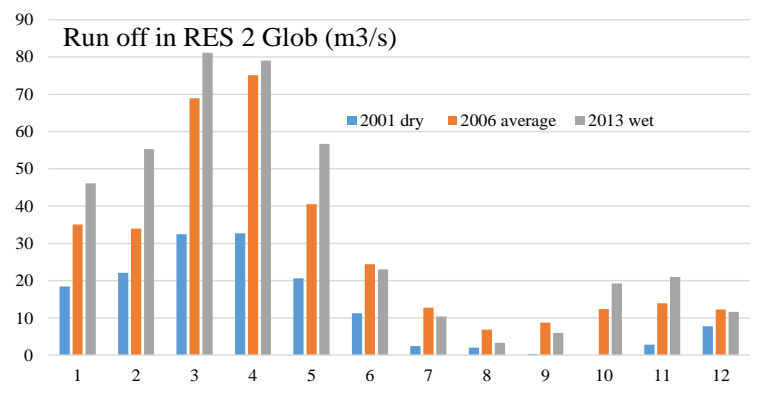

Fig. 3. Monthly water inflows for the RES 2 of Ohrid Lake

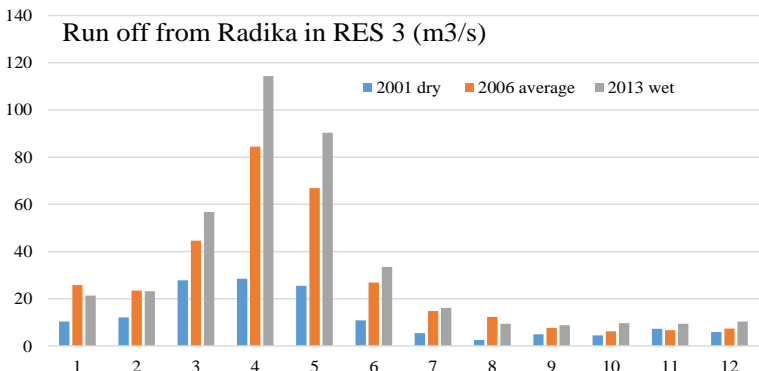

Fig. 4. Monthly water inflows for the RES 3 of Debar Lake from the Radika river

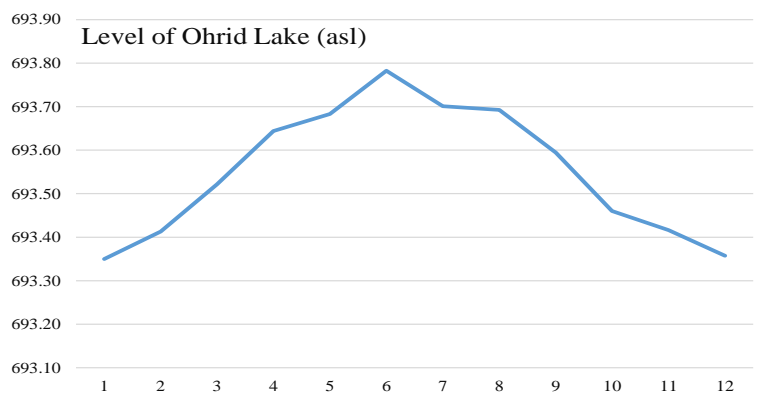

Fig. 5a. Reservoir level of Ohrid Lake in wet 2013

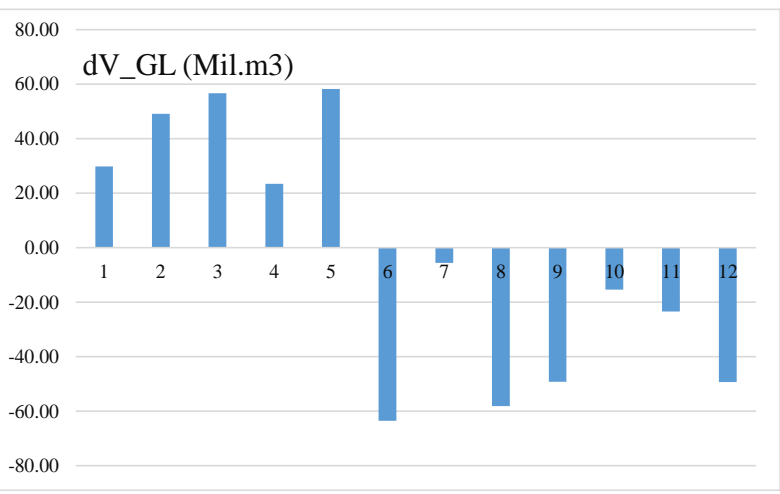

Fig. 5b. Spent volume of water in HPP Globočica for each month in wet 2013 
Figures $6 \mathrm{a}$ and $6 \mathrm{~b}$ present the results for the reservoir level of Debar Lake and the used volume of water for HPP Špilje (dV_SP), respectively.

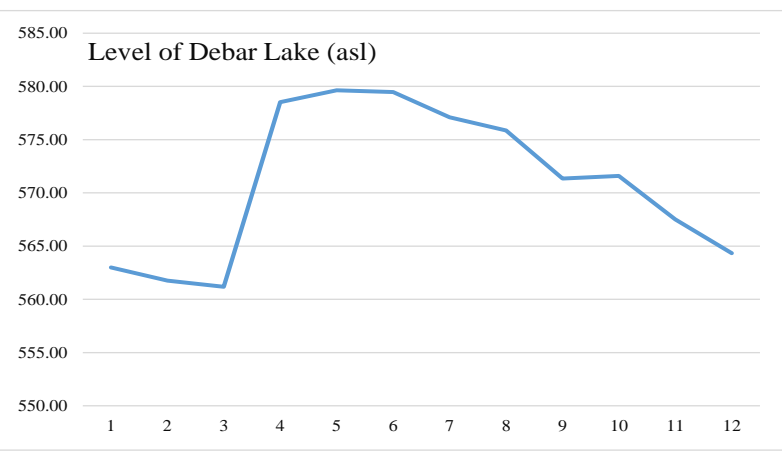

Fig. 6a. Reservoir level of Debar Lake in wet 2013

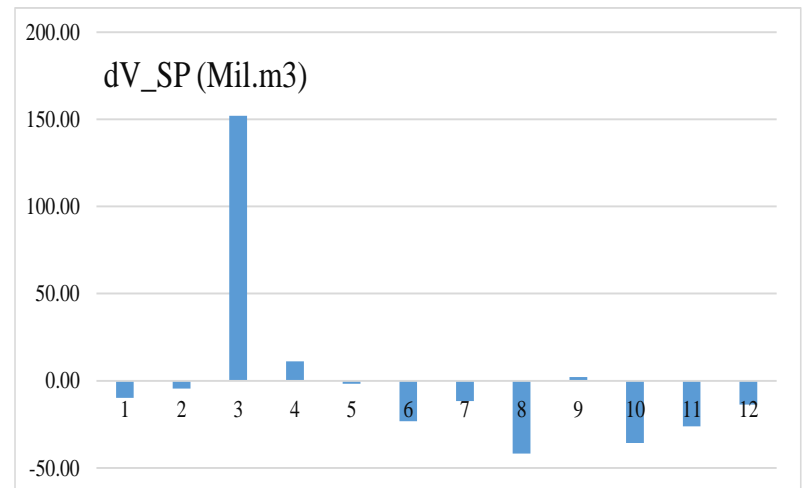

Fig. 6b. Spent volume of water in HPP Špilje for each month in wet 2013

For LT operation modes, the reversible HPP Tašmaruništa is not considered, but only the conventional HPP Špilje and HPP Globočica (Figure 7).

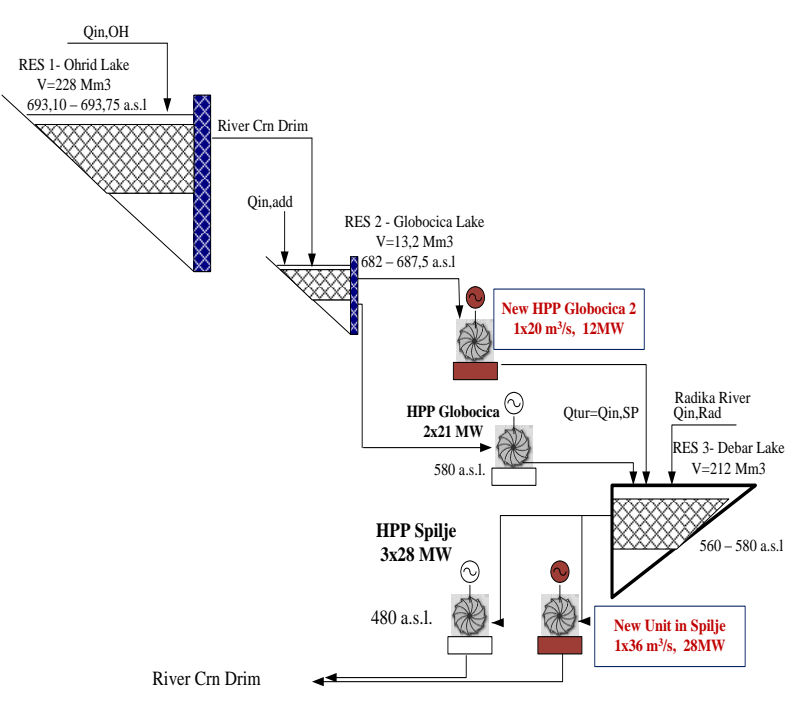

Fig. 7. HPS considering for long-term (LT) operation modes
In order to avoid overflowing and spilling, the operation with maximum installed turbine flow for both HPPs is in the first months. The total balance of the both HPPs in the HPS on Crn Drim in generated electricity and financial income from the sold electricity is given in Table 4 . The total generated electricity consists of 2 parts, base and peak part, in where the income results from, and the third part is lost electricity (negative one) because spilling. Therefore, for wet 2013, all HPPs in the HPS of Crn Drim give:

- Production of around $658 \mathrm{GWh}$ with total electricity sale of approximately 34.3 million euros.

- Overflow (spillway) of about $36 \mathrm{GWh}$ with a total loss of un-produced electricity of about 1.2 million euros.

Ta b le 4

Generated electricity and financial income for the wet 2013 in case with existing and additional units in the HPS of Crn Drim

\begin{tabular}{|c|c|c|c|c|c|c|}
\hline & \multicolumn{3}{|c|}{$\begin{array}{c}\text { Generated electricity } \\
W(\mathrm{MWh})\end{array}$} & \multicolumn{3}{|c|}{$\begin{array}{l}\text { Financial income } \\
\text { FIN (mil.Euros) }\end{array}$} \\
\hline & Base & Peak & Spill & Base & Peak & Spill \\
\hline 1 & 0 & 39717 & 0 & 0.00 & 2.13 & 0.00 \\
\hline 2 & 0 & 35525 & 0 & 0.00 & 2.09 & 0.00 \\
\hline 3 & 31329 & 23489 & 0 & 1.27 & 1.52 & 0,00 \\
\hline 4 & 90595 & 36202 & -36202 & 2.89 & 1.67 & -1.20 \\
\hline 5 & 63037 & 15665 & 0 & 2.66 & 1.41 & 0.00 \\
\hline 6 & 35456 & 27876 & 0 & 1.82 & 2.42 & 0.00 \\
\hline 7 & 0 & 26575 & 0 & 0.00 & 1.43 & 0.00 \\
\hline 8 & 0 & 43686 & 0 & 0.00 & 2.84 & 0.00 \\
\hline 9 & 0 & 32167 & 0 & 0.00 & 2.26 & 0.00 \\
\hline 10 & 0 & 33289 & 0 & 0.00 & 3.07 & 0.00 \\
\hline 11 & 0 & 31409 & 0 & 0.00 & 3.06 & 0.00 \\
\hline 12 & 0 & 31811 & 0 & 0.00 & 3.00 & 0,00 \\
\hline $\mathrm{S}$ & 220417 & 377410 & -36202 & 8.63 & 26.91 & -1.20 \\
\hline & Total & 657990 & & & 34.35 & \\
\hline
\end{tabular}

Figure 8 gives graphical presentation of the generated electricity in each month for the whole HPS of Crn Drim in 2013. The lost electricity because spilling is negative (below the horizontal axis in month of April). 


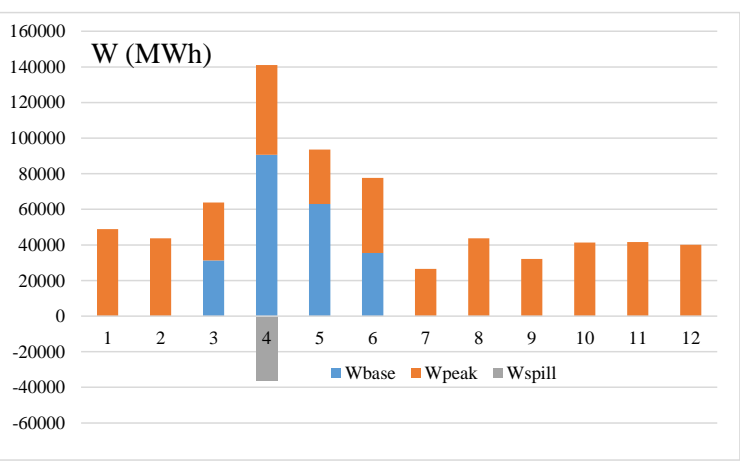

Fig. 8. Monthly production for the HPS Crn Drim in wet 2013

According to the calculation performed for all cases and for all representative years, results are compared and analyzed in order to provide answer about the benefit of additional units installed in the HPS of Crn Drim, which is useful for further techno-economic analyses. Table 5 and Figure 9 show the generated electricity and lost energy in spilling, for all representative years.

\section{Table 5}

Generated electricity and spilled energy in $M W h$ for all cases for the HPS of Crn Drim

\begin{tabular}{cccc}
\hline \hline & Dry 2001 & Aver. 2006 & Wet 2013 \\
\hline$W_{\text {base }}$ & 0 & 88440 & 220417 \\
$W_{\text {peak }}$ & 194431 & 498460 & 473774 \\
$W_{\text {spill }}$ & 0 & 0 & -36202 \\
\hdashline Total & 194431 & 586900 & 657990 \\
\hline \hline
\end{tabular}

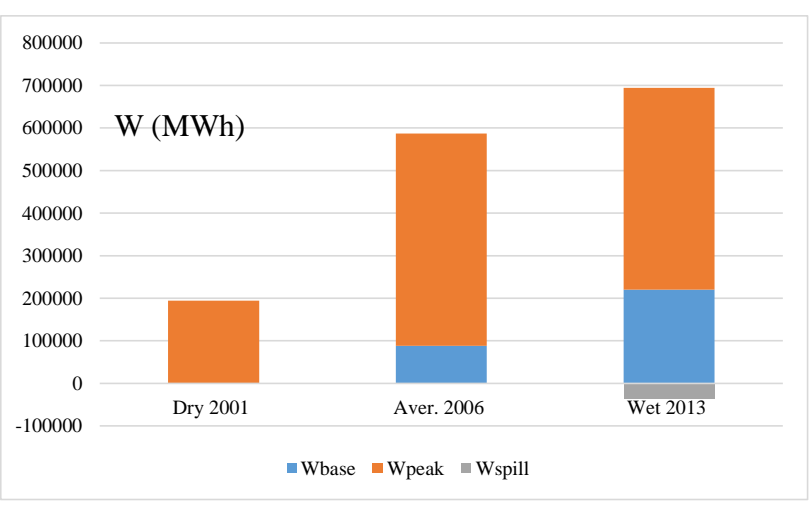

Fig. 9. Comparing the output energy for all cases

The results show that the increased production and income can be got in additional units in peak tariffs with high prices. Another benefit resulting from the use of additional units is having reduced the lost energy of the spilling in wet 2013 down to $36202 \mathrm{MWh}$, and the difference goes to additional peak electricity of the system. Table 6 and Figure 10 show the income obtained from the generated electricity in euros by taking into account the lost energy resulting from spilling.

Table 6

Financial benefit from the income (in $\epsilon$ ) for all cases for the HPS of Crn Drim

\begin{tabular}{lccc}
\hline \hline & Dry 2001 & Aver. 2006 & Wet 2013 \\
\hline FIN $_{\text {base }}$ & 0 & 3866861 & 8634785 \\
FIN $_{\text {peak }}$ & 10785275 & 28128836 & 26909732 \\
FIN $_{\text {spill }}$ & 0 & 0 & -1196258 \\
\hline Total & 10785275 & 31995696 & 34348258 \\
\hline \hline
\end{tabular}

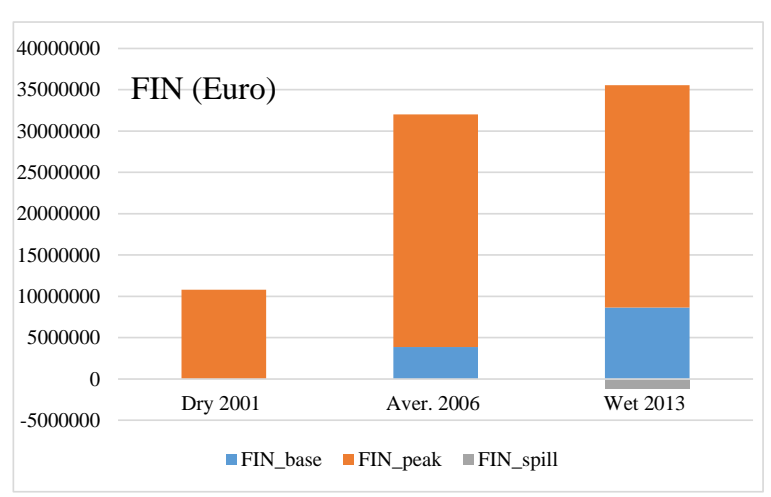

Fig. 10. Comparing the income (in $€$ ) for all cases

The overall benefit are: for the dry 2001 is approximately $10.5 \mathrm{M} €$, for the average 2006 is approximately $32 \mathrm{M} €$ and for the wet 2013 is approximately $34.2 \mathrm{M} €$.

\subsection{Short-term (ST) operation modes for the HPS of Crn Drim}

The simulations of ST operating modes for the HPS of Crn Drim are performed for some characteristics days, with the inputs taken from the LT results especially water inflows and turbine discharges. The main point in ST planning is focused on the operation of the reversible HPP of Tašmaruništa with the HPP of Globočica (Figure 11), and the water managing between downstream RES 2 of Globočica and upstream RES 4 of Tašmaruništa. The LT operation modes are made on the hourly time interval ( $t=1$ hour) during the whole period of a year ( $T=1$ day/week). In this way, the operation of 
turbine mode in the peak and/or rush hours $(7-24$ h) and pumping mode in off hours $(0-6 \mathrm{~h})$ within the day can be found.

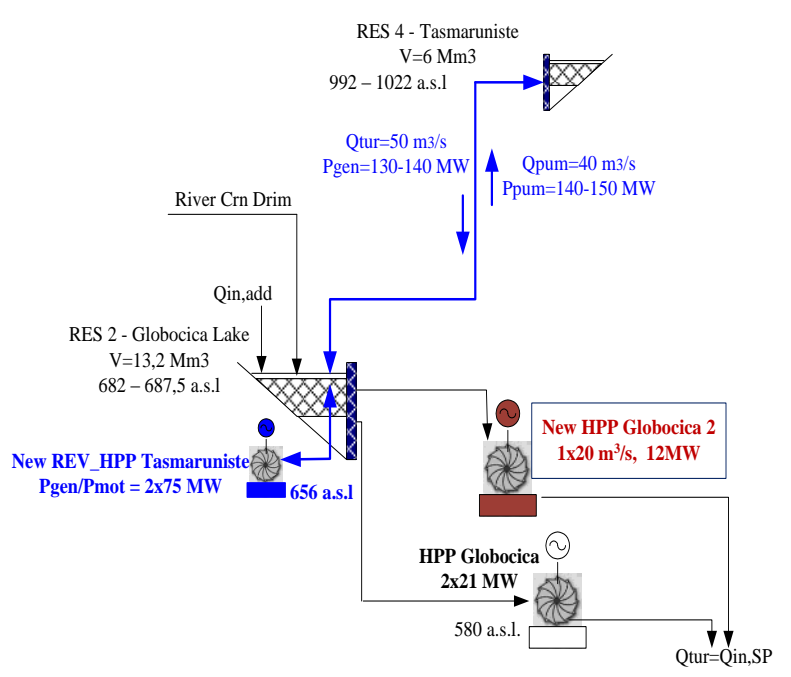

Fig. 11. HPS considering for short-term (ST) operation modes

According to [3], by taking into account water losses and the efficiencies of turbine and generator, the power output (in $\mathrm{kW}$ ) injected to the grid in turbine-generation mode for Rev HPP is:

$$
P_{\text {gen }}(t)=9.81 \cdot \eta_{\text {tur }} \cdot \eta_{\text {gen }} \cdot Q_{\text {tur }}(t) \cdot H_{\text {net }}(t) \text {. }
$$

Besides, by taking into account water losses and pump and motor efficiencies, the power in $\mathrm{kW}$ taken from the grid as a consumer of pump-motor mode for Rev HPP can be obtained as:

$$
P_{\text {mot }}(t)=\frac{9.81 \cdot Q_{\text {pum }}(t) \cdot H_{\text {net }}(t)}{\eta_{\text {pum }} \cdot \eta_{\text {mot }}} .
$$

The time periods for each day are divided in hourly time intervals, and for financial analysis it is taken 4 tariffs (Figure 12), night, medium, peak and rush tariff.

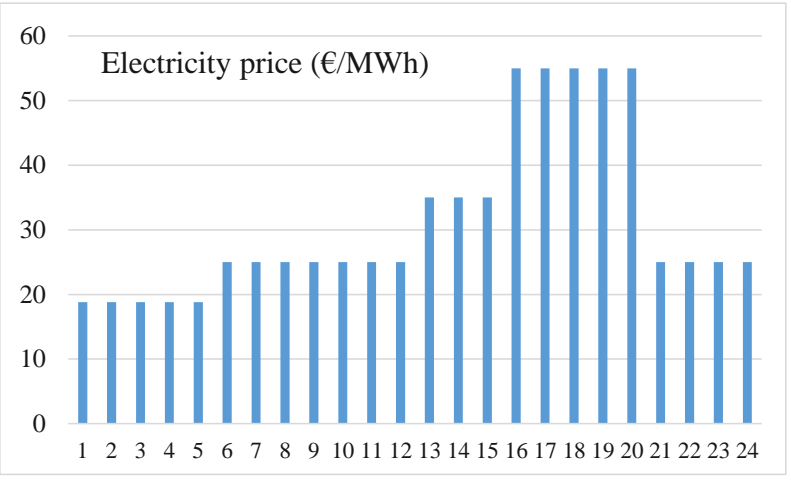

Fig. 12. Daily tariffs of electricity price

\subsection{Daily operation ST mode (24 hours)}

Figure 13 presents the turbine and pump flows in a day (24 hours) for the reversible HPP of Tašmaruništa in a case of large inflow in RES 2 - Globočica Lake of $Q_{\text {in }}=32 \mathrm{~m}^{3} / \mathrm{s}$. The generated powers as shown in Figure 14 from the three HPPs (P1 - Globočica 1, P2 - Globočica 2, and Pg_TAS - Tašmaruništa), are determined according to (7). The power of the pumping mode is Pp_TAS and it is obtained according to (8).

$$
\begin{gathered}
P_{\mathrm{gen}}(t)=P_{\mathrm{P}_{\mathrm{GL}}}(t)+P_{\mathrm{P} 2_{\mathrm{GL}}}(t)+P_{\mathrm{g}_{\mathrm{TAS}}}(t) \\
P_{\mathrm{pum}}(t)=P_{\mathrm{p}_{\mathrm{TAS}}}(t)
\end{gathered}
$$

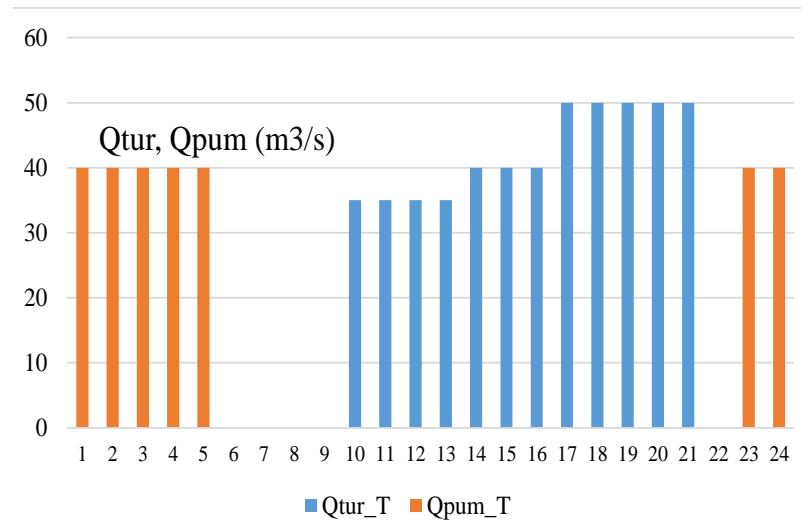

Fig. 13. Turbine and pump flows for the rev. HPP of Tašmaruništa

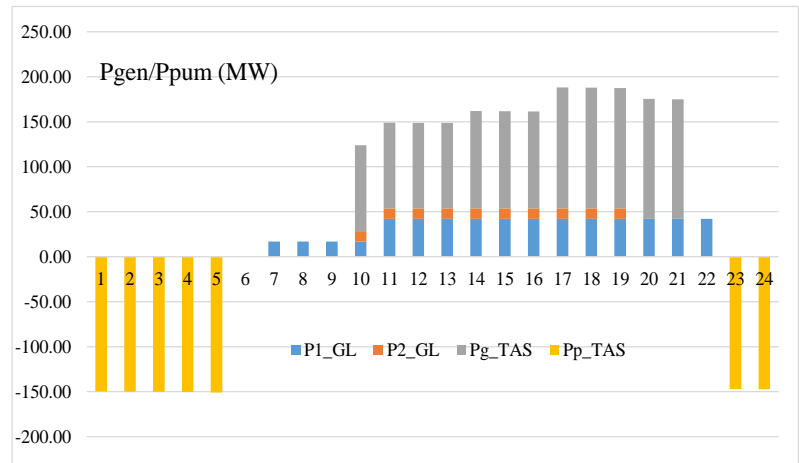

Fig. 14. Generated and consumed power for the HPS on Figure 11

The graphs of the reservoir level for the downstream RES 2 - Globočica, and the upper RES 4 - Tašmaruništa are shown in Figures 15 and 16, respectively.

The ratio between the volumes used for pumping and for generation electricity is $V \mathrm{p} / \mathrm{Vt}=0.55$ and for this amount of water, the ratio of the energies needed for pumping and generation is $W \mathrm{p} / W \mathrm{t}=0.76$. 


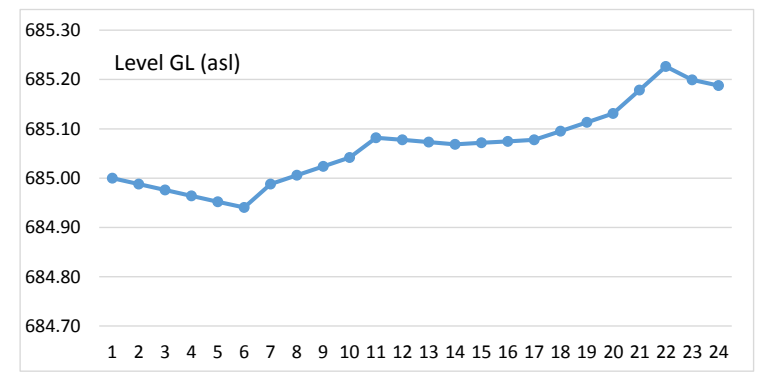

Fig. 15. Water level for downstream RES 2 - Globočica

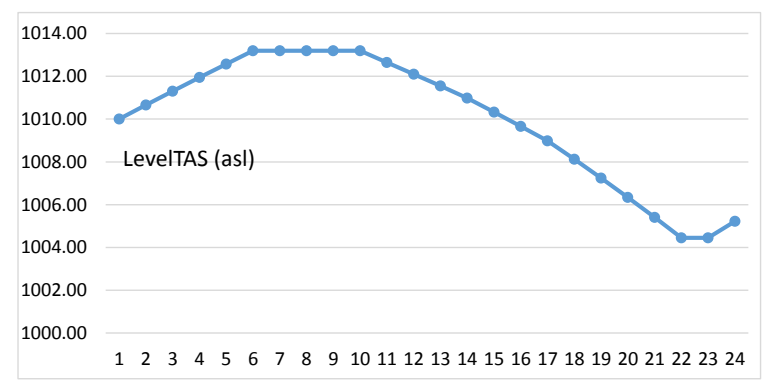

Fig. 16. Water level for upper RES 4 - Tašmaruništa

\subsection{Days operation ST mode (72 hours) Low inflow}

The other ST simulation is done for a 3-day (72 hours) operation mode for a low runoff for RES 2 Globočica Lake, which is $Q_{\text {in }}=12 \mathrm{~m}^{3} / \mathrm{s}$, and the appropriated results are shown in Figures 17 and 18. The ratio between the volumes used for pumping and for generation electricity is $V \mathrm{p} / V \mathrm{t}=0.32$, and for this amount of water, the ratio of the energies needed for pumping and generation is $\mathrm{Wp} / W \mathrm{t}=$ 0.45 .

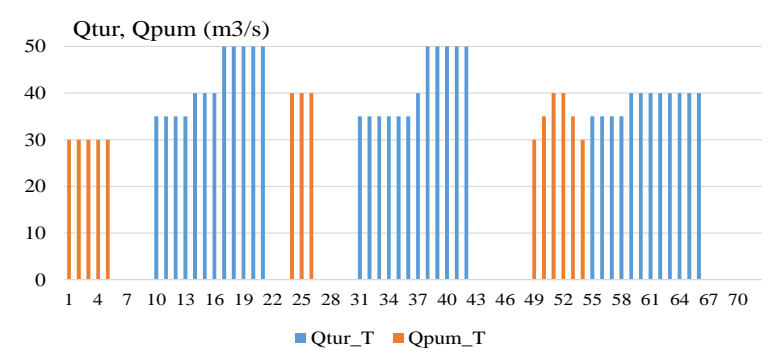

Fig. 17. Turbine and pump flows for 3 days operation

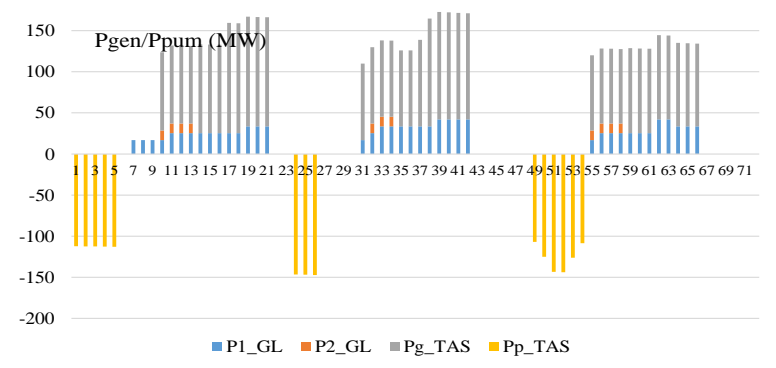

Fig. 18. Generated and consumed power for 3 days operation
The operation mode for each time period of an hour, can be defined by the system operator requirements and the electricity demand, but it should take into account the condition of minimum and maximum allowed levels for each system reservoir.

\subsection{Weekly operation ST mode (168 hours) High inflow}

The other ST simulation is done for a 7-days (168 hours) operation mode, for a high runoff for RES $2-$ Globočica Lake, which is $Q_{\text {in }}=28.3 \mathrm{~m}^{3} / \mathrm{s}$, and the appropriated results are shown in Figures 19 and 20. In order to avoid spilling in this case, it is necessary to have a near equal amount of water in the generating and in the pumping mode. The ratio between the volumes used for pumping and for generation electricity is $V_{\mathrm{p}} / V_{\mathrm{t}}=0.93$, and for this amount of water, the ratio of the energies needed for pumping and generation is $W_{\mathrm{p}} / W_{\mathrm{t}}=1.30$.

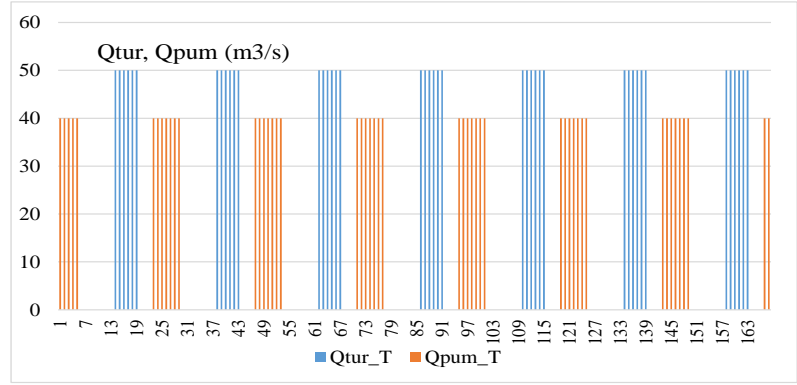

Fig. 19. Turbine and pump flows for 7 days operation

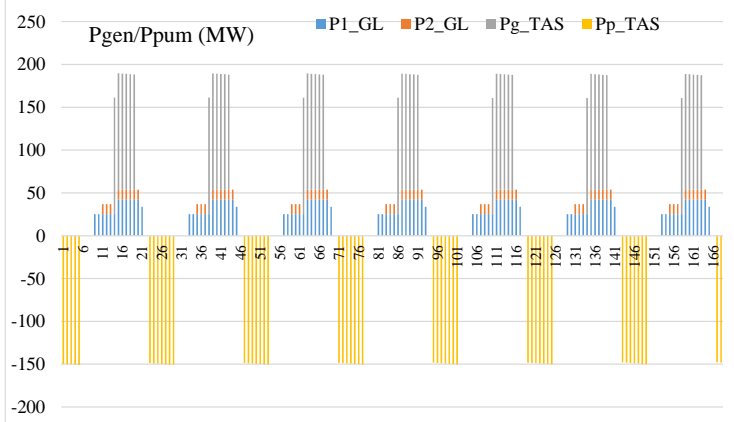

Fig. 20. Generated and consumed power for 7 days operation

Each day (24 hours) in a weekly operation regime has the same generation and pumping modes (in hour's duration and flow rate). It is important to avoid spilling of the downstream reservoir of Globočica for a high inflow rate in it. At the same time, the operations of the HPP Globočica 1 and HPP Globočica 2 are in high tariffs each day. By taking into account these operating conditions, the 
reservoir level of the downstream and the upstream reservoirs are on the same level for each 24 hours interval (Figures 21 and 22).

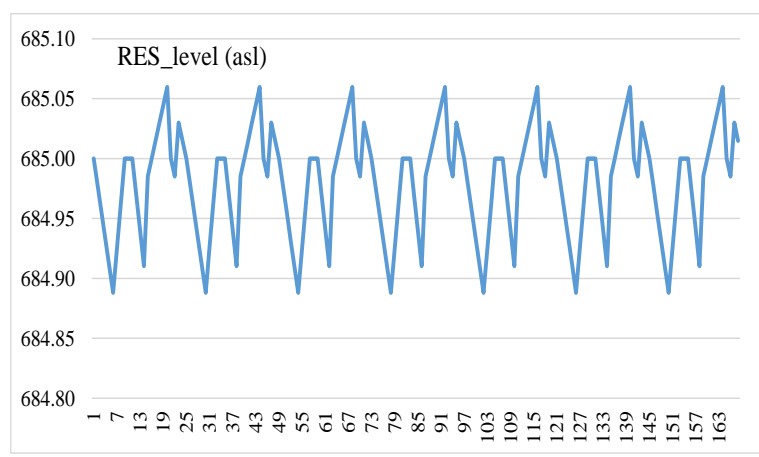

Fig. 21. Level of the downstream reservoir of Globočica according operation modes

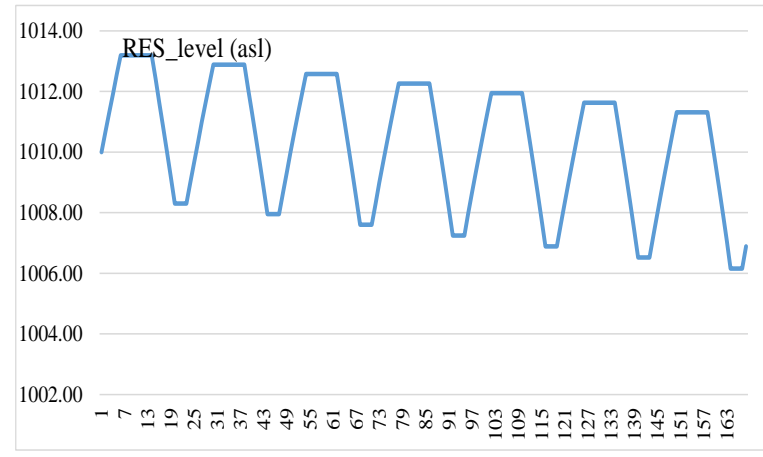

Fig. 22. Level of the upstream reservoir of Tašmaruništa according operation modes

For this case, for a weekly operation and for a high inflow rate in the downstream reservoir of Globočica, the outputs are as the following:

Water balance: Total inflow in the RES of Globočica is $V_{\text {inflow }}=17.14 \mathrm{Mm}^{3}$, and the water consumption for each HPP is shown in Table 7

\section{Ta b le 7}

Water weekly consumption (in $\mathrm{Mm}^{3}$ ) for each HPP

\begin{tabular}{cccc}
\hline \hline$V_{-G L 1}$ & $V_{-}$GL2 & $V_{\text {gen_TAS }}$ & $V_{\text {pum_TAS }}$ \\
\hline 13.10 & 4.54 & 7.56 & 7.06 \\
\hline \hline
\end{tabular}

Therefore, the total water balance $\mathrm{d} V=0$, or:

$\mathrm{d} V=V_{\text {inflow }}-V_{-}$GL1 $-V_{-G L 2}-V_{\text {gen_TAS }}+V_{\text {pum_TAS }}=0$.

Energy output: The total energy in the same week for all HPPs are is presented in Table 8
Table 8

Energy production and consumption (in MWh) for each HPP

\begin{tabular}{cccc}
\hline \hline$W_{\text {GGL1 }}$ & $W_{-}$GL2 & $W_{\text {gen_TAS }}$ & $W_{\text {pum_TAS }}$ \\
\hline 3066 & 735 & 5668 & -7318 \\
\hline \hline
\end{tabular}

Therefore, the total energy balance is:

$$
\begin{aligned}
& \mathrm{d} W=\left(W_{\mathrm{GL} 1}+W_{\mathrm{GL} 2}+W_{\mathrm{gen}_{\mathrm{TAS}}}\right)-W_{\mathrm{pum}_{\mathrm{TAS}}} \\
& \mathrm{d} W=W_{\text {gen }}-W_{\text {pum }}=9467-7318=2150 \mathrm{MWh}
\end{aligned}
$$

Financial output: According to the energy production and the consumption of each HPP, and by taking into account the electricity prices for each tariff from Figure 12, the financial output of all HPPs is presented in Table 9.

T a b l e 9

Financial balance (in $€$ ) for each HPP

\begin{tabular}{cccc}
\hline \hline F_GL1 & F_GL2 & Fgen_TAS $_{1}$ & Fpum_TAS $_{\text {p }}$ \\
\hline 127339 & 32278 & 273743 & -150463 \\
\hline \hline
\end{tabular}

Therefore, the total financial balance is:

$$
\begin{aligned}
& \mathrm{d} F=\left(F_{\mathrm{GL} 1}+F_{\mathrm{GL} 2}+F_{\text {gen }_{\mathrm{TAS}}}\right)-F_{\text {pum }_{\mathrm{TAS}}} \\
& \mathrm{d} F=F_{\text {gen }}-F_{\text {pum }}=433360-50463=282897 €
\end{aligned}
$$

The total financial income in a week is 282897 $€$ of which $159617 €$ are from both HPPs of Globočica $(127339+32278)$, and the rest $123280 €$ are from the reversible HPP of Tašmaruništa (273743 - 50463).

The design of both reservoirs downstream RES 2 - Globočica and upstream RES 4 - Tašmaruništa, have enough water capacity for daily-weekly regulations in a system for installed turbine-pump flow of $50-40 \mathrm{~m}^{3} / \mathrm{s}$. It should be mentioned, that in this case for ST operation modes, it is not included the operation mode of HPP Špilje, which is down stream of the HPPs Globočica.

\section{CONCLUSION}

The operating modes of the hydropower system depend on the turbine/pump and generator/motor installations for all units of a conventional and/or reversible HPP. They also depend on the electricity 
needs and system operator requirements. Anyway, more units in the HPS means more flexible operation of the whole system.

For LT operation modes, large reservoirs with conventional units can be considered, however, they depend on the available data needed in terms of hydrology (day, week or month).

For ST operation modes, the hourly operation for each power unit can be considered, by taking into consideration a reversible HPP. In this case, the flexibility of the system can be improved and maximum financial profit from electricity generation can be obtained. One should note that the ratio between peak tariff and low off tariff is large then the ratio between generated and pumped power for same amount of water $\left(C_{\text {peak }} / C_{\text {off }}>P_{\text {gen }} / P_{\text {pum }}\right)$.

The benefits of complex hydropower system operation should be valorized in generated electricity, and in financial benefit. Some of the additional analyses that can be done, are:

- Higher electricity production as a result of utilization of the overflow spilling water.

- Engagement of units in the periods of high tariffs per day, rather than production as a base plant.

- Opportunity for optimization of the whole hydropower system with all units in the HPS.
- Optimization of the HPS and avoiding overflows, in order to obtain positive financial effects from the operation the entire hydrosystem.

- Possibility for regulating the water flows of runoffs, and regulating the reservoirs.

The main driven conditions for the operation modes of the HPS depend on the complexity of the hydropower system from the technical point of view (number of power units and reservoirs with their connectivity), and the available hydrological data, as well as the operation and/or utility requirements.

\section{REFERENCES}

[1] GEING and FICHTNER, Crn Drim River Basin, Study on Optimum Utilization of Hydropower Potential, Final Report, April 2016.

[2] JSC ELEM, Reports on Data for HPS of Crn Drim, HPP Globočica and HPP Špilje, Skopje.

[3] Čakar and Partners, Study for pump storage hydropower plant Tašmaruništa, made for ELEM, Skopje 2010.

[4] VALORAGUA-A, Model for the Optimal Operating Strategy of Mixed Hydrothermal Generating Systems, 1992, IAEA, Vienna, Austria.

[5] Dozier, André: Integrated Water and Power Modeling Framework for Renewable Energy Integration, Colorado State University, Colorado, USA, 2012. 